\title{
Peroral Endoscopic Myotomy for Achalasia Combined with Submucosal Marsupialization of an Epiphrenic Diverticulum
}

\author{
Ricardo Rio-Tinto ${ }^{a}$ Miguel Bispo $^{a}$ Paulo Fidalgo ${ }^{a}$ Jacques Devière ${ }^{a, b}$ \\ ${ }^{a}$ Digestive Oncology Unit, Champalimaud Foundation, Lisbon, Portugal; b Department of Gastroenterology, \\ Hepatopancreatology, and Digestive Oncology, Erasmus University Hospital - Université Libre de Bruxelles, \\ Brussels, Belgium
}

Keywords

Achalasia · Advanced endoscopy · Esophageal

diverticulum $\cdot$ Peroral endoscopic myotomy

\section{Miotomia endoscópica peroral para tratamento de acalásia em combinação com marsupialização submucosa de divertículo epifrénico}

\section{Palavras Chave}

Acalásia · Divertículo esofágico · Endoscopia avançada . Miotomia endoscópica peroral

Although developed as a technique for the treatment of achalasia, peroral endoscopic myotomy (POEM) has recently emerged as a therapeutic tool for other diseases such as diffuse spasm, nutcracker esophagus, and gastroparesis (G-POEM), and there is increasing evidence on its safety and efficacy. The potential applications of endoscopic tunneling and cutting seem to have no limits.

A 59-year-old woman with a 10 -year history of dysphagia and a transhiatal resection surgery on an epiphrenic diverticulum 5 years previously was referred to

\section{KARGER}

E-Mail karger@karger.com www.karger.com/pjg (c) 2019 Sociedade Portuguesa de Gastrenterologia Published by S. Karger AG, Basel

Karcer

Open access

This article is licensed under the Creative Commons AttributionNonCommercial-NoDerivatives 4.0 International License (CC BYNC-ND) (http://www.karger.com/Services/OpenAccessLicense). Usage and distribution for commercial purposes as well as any distribution of modified material requires written permission. our center due to progressive worsening of the dysphagia following surgery. Recurrence of the epiphrenic diverticulum was documented and type 3 achalasia was diagnosed, with an Eckardt score of 8 [1]. POEM, eventually combined with submucosal marsupialization of the epiphrenic diverticulum, was then proposed.

With the patient under general anesthesia, an upper endoscopy was performed (Fig. 1a). A mucosal incision was made $27 \mathrm{~cm}$ from the incisors, and anterograde submucosal tunneling was conducted laterally to the diverticulum pouch. The submucosal tunnel allowed reaching the lateral segment of the proximal end of the septum, where the submucosal space is divided by the septal muscle fibers (Fig. 1b). The submucosal tunnel was extended downstream up to 2 $\mathrm{cm}$ below the cardia, and the circular layer of the muscular wall was sectioned up to $3 \mathrm{~cm}$ above the gastroesophageal junction. Next, an anterograde septotomy was performed, creating a submucosal marsupialization of the diverticulum (Fig. 1b, c). The inner circular muscle layer was sectioned over an additional $3 \mathrm{~cm}$ over the septum (Fig. 1e), and the tunnel entry was closed with 5 clips. There were no adverse events. An immediate improvement in symptoms was noticed, and the patient remained asymptomatic (with an Eckardt score of 0) 12 months after the procedure. Follow-up esophagography illustrated marsupialization of the 

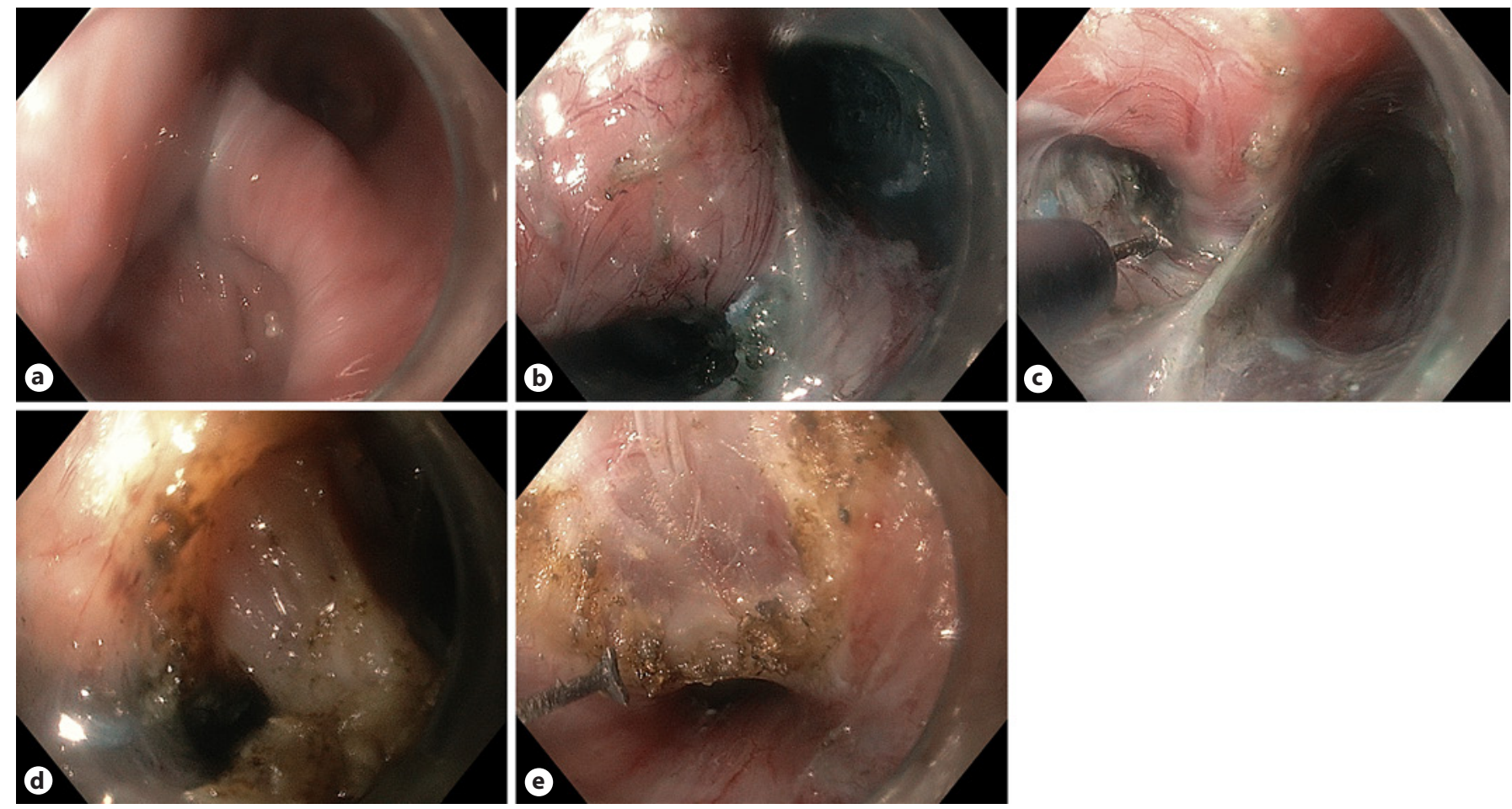

Fig. 1. Endoscopic images. a Luminal view before submucosal tunneling. b Muscular septum of the epiphrenic diverticulum in the submucosal tunnel. c, d Anterograde septotomy in the submucosal tunnel. e Inner-layer myotomy proximal to the diverticulum.
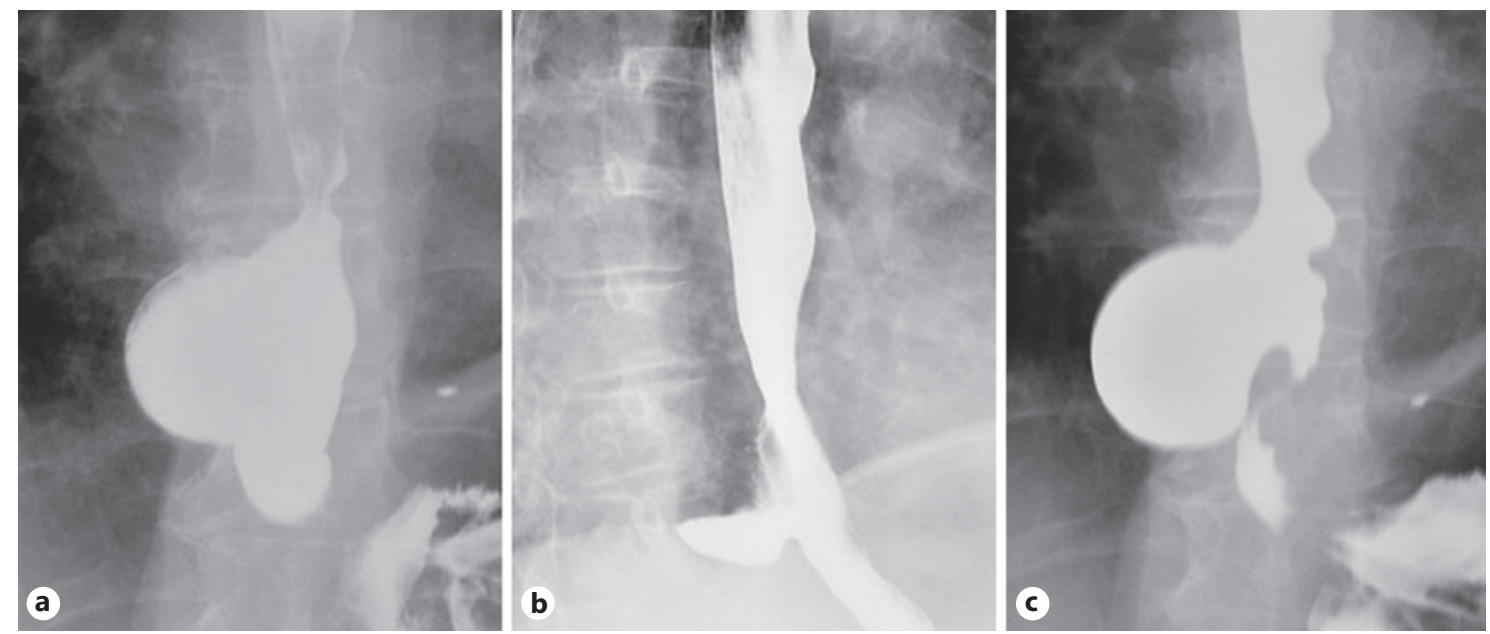

Fig. 2. Barium study showing a large epiphrenic diverticulum. a, b After treatment. c Before treatment.

diverticulum and easy passage of contrast through the cardia (Fig. 2a, b), compared with the evident diverticular septum before the myotomy (Fig. 2c).

POEM is a promising minimally invasive endoscopic procedure for the treatment of achalasia, with favorable long-term outcomes [2,3]. When achalasia is associated with a large epiphrenic diverticulum, treatment typically involves surgical myomectomy or diverticulectomy, which is associated with high morbidity [4]. However, a purely endoscopic technique, with a two-step approach, 
has recently been described: POEM, followed by the creation of a fistula from the esophageal diverticulum to the gastric fundus using a lumen-apposing metallic stent [5]. This case report demonstrates a single-session, modified POEM technique for the management of an epiphrenic diverticulum in the context of achalasia which was clinically effective in the long term.

\section{Disclosure Statement}

The authors have no conflicts of interest.

\section{References}

1 Eckardt AJ, Eckardt VF. Treatment and surveillance strategies in achalasia: an update. Nat Rev Gastroenterol Hepatol. 2011 Jun; 8(6):311-9.

2 Inoue H, Sato H, Ikeda H, Onimaru M, Sato $\mathrm{C}$, Minami H, et al. Per-oral endoscopic myotomy: a series of 500 patients. J Am Coll Surg. 2015 Aug;221(2):256-64.

3 Li QL, Wu QN, Zhang XC, Xu MD, Zhang W, Chen SY, et al. Outcomes of per-oral endoscopic myotomy for treatment of esophageal achalasia with a median follow-up of 49 months. Gastrointest Endosc. 2018 Jun;87(6): 1405-1412.e3.
4 Zaninotto G, Portale G, Costantini M, Zanatta L, Salvador R, Ruol A. Therapeutic strategies for epiphrenic diverticula: systematic review. World J Surg. 2011 Jul;35(7):1447-53.

5 Tieu AH, Kumbhari V, Ngamruengphong S, Haito-Chavez Y, Chen YI, Bukhari M, et al. Two-stage endoscopic approach for the management of a large symptomatic epiphrenic diverticulum in the setting of achalasia. Gastrointest Endosc. 2016 Nov;84(5):848-9. 